\title{
Prospects for Economic Use of Polylectic, Sternotribic, Vibratile Insect Pollinators in Tomato Hybridization
}

\author{
S.J. Warnock ${ }^{1}$ \\ Campbell Research and Development, 28605 County Road \#104, Davis, CA 95616
}

\begin{abstract}
Insect pollinator-crop relationships are of immediate concern in breeding of most economic crops and may be important in commercial seed production. On the one hand, insects must be excluded or controlled to maintain purity in breeding material, while on the other they may be an important adjunct to effect pollination for adequate seed production. Rick (1947) recognized that controlled insect pollination in tomato ( $L y$ copersicon esculentum Mill.) could be a valuable asset in the production of hybrid tomato seed. The components are present for an insect-pollinated system of hybrid seed production, but use of insects for tomato hybridization has not come about, although hybrid tomato seed is now used consistently in commercial production of processing and fresh-market tomatoes.

Insects do visit tomato flowers. Visitants are types that also visit other plant species, particularly solanaceous species, that poricidally shed pollen. But little is known of the complex aspects of the insect-tomato flower relationship and how it might be controlled. It is the purpose of this paper to review the present status of the subject and suggest new research avenues.
\end{abstract}

\section{VIBRATILE POLLINATORS}

Throughout the world, $>15,000$ plant species $(\approx 6 \%$ to $8 \%$ of named species $)$ in 544 genera and 72 families shed pollen poricidally (Buchmann, 1986). These species are pollinated by vibratile pollinators, more commonly called "buzz" pollinators. Pollinators are mostly bees, but syrphid flies also may pollinate occasionally (Buchmann et al., 1977; Knapp, 1986). Pollinators approach flowers and position themselves over the pistil and anther cone by grasping the anthers or the corolla and anthers (Buchmann et al., 1977; Michener, 1962). The anther cone is vibrated by the insect for one or several short periods with the indirect flight muscles (Buchmann et

Received for publication 13 Apr. 1992. Accepted for publication 1 July 1992. The cost of publishing this paper was defrayed in part by the payment of page charges. Under postal regulations, this paper therefore must be hereby marked advertisement solely to indicate this fact.

'Retired. Please direct correspondence to 318 Mills Drive, Davis, CA 95616. al., 1977). Pollinators may rotate on the anther cone between vibrations (Buchmann et al., 1977). Some insects work stamens individually (Symon, 1976). During vibration, pollen is expelled through the pores and onto the sternum or venter of the insect. The flower is pollinated in the process of this pollen collection. Pollen transfer from the sternum or venter to the scopae is accomplished by use of the legs. Residual pollen on the sternum may effect outcrossing in species so adapted, hence sternotribic.

These buzz pollinators are considered polylectic. They visit many flowers of various species and different genera, poricidal or nonporicidal, collecting pollen as floral conditions dictate, either by buzz pollination or foraging in the more conventional manner as represented by Apis mellifera L., the common honeybee. Michener (1962) suggests that visits to poricidal stamen types are few compared with the total flowers approached. The honeybee, for unknown reasons, does not collect by buzz pollination (Buchmann et al., 1977; Michener, 1962). Either it has never learned this manner of collection, or it is anatomically incapable of effecting collection by this method (Buchmann et al., 1977).

The ability to buzz pollinate is inherited. Some stimuli must induce engagement in this behavior, and each individual insect has to learn how to collect pollen from poricidally pollen-shedding plants by vibration (Buchmann et al., 1977; Michener, 1962). Only the females serve as buzz-pollen collectors. Males collect nectar only. Bees from several genera of several families have the ability to buzz pollinate.

Table 1. Distribution of vibratile pollinators visiting Lycopersicon spp. in Peru. ${ }^{2}$

\begin{tabular}{|c|c|c|c|c|}
\hline Pollinator species & $\begin{array}{l}\text { Lycopersicon } \\
\text { esculentum }\end{array}$ & $\begin{array}{l}\text { Lycopersicon } \\
\text { pimpinellifolium }\end{array}$ & $\begin{array}{l}\text { Lycopersicon } \\
\text { hirsutum }\end{array}$ & $\begin{array}{l}\text { Lycopersicon } \\
\text { peruvianum }^{y}\end{array}$ \\
\hline Lonchopria sp. & -.- & --- & 1 & --- \\
\hline Augochlora nigromarginata & 21 & 2 & -.. & 1 \\
\hline Augochlora matucanensis & $\cdots$ & -- & 1 & --- \\
\hline Anthophora tricincta & -.- & --- & --- & 3 \\
\hline Anthophora arequipensis & $\ldots$ & --- & --- & 1 \\
\hline Exomalopsis bruesi & 2 & -.- & ... & 1 \\
\hline Thygater albiceps & -.. & --- & --- & 1 \\
\hline Xylocopa brasilianorum & $\ldots$ & ... & $\cdots$ & 1 \\
\hline Xylocopa sp. & -.- & --- & 1 & -.- \\
\hline Centris surinamensis & --- & $\cdots$ & 1 & $\cdots$ \\
\hline Bombus funebris & --. & --- & --. & 4 \\
\hline
\end{tabular}

${ }^{2}$ Rick, 1950 .

'Includes L. glandulosum.

\section{VIBRATILE POLLINATION IN THE SOLANACEAE}

Vibratile pollination in Solanaceae has been reviewed by Symon (1976) and Buchmann (1983). Symon (1976) and Whalen (1984) considered the earliest explicit descriptions of vibratile pollinations in Solanum to be those of Michener (1962) and Linsley and Cazier (1963). Members of Solanum all shed pollen through pores. Two other Solanaceae genera are also poricidal, Cyphomandra and $L y$ cianthes. Lycopersicon, although its anthers open by apical slits, is functionally poricidal (Buchmann, 1986).

Buzz pollinators are attracted to Solanum flowers by both visible and ultraviolet light spectra (Buchmann et al., 1977). The complete floral arrangement, the whole plant, or groups of plants may also serve as attractants (Whalen and Costich, 1986). Bees may be attracted to pollen by other means as well. Buchmann (1986) studied pollen chemistry, thinking that insects might be attracted by chemical content. He found no differences in $\mathrm{N}$ content for pollen from solanaceous species with pore-shedding anthers and those that are nonporicidal. Buchmann et al. (1977) demonstrated that the pollen of Solanum dougkasii Dun. and S. xanti Gray had osmophores but offered no evidence that bees responded to their presence. While considered polylectic, there is evidence that pollinators may be limited in the species visited, at least for vibratile pollination (Table 1). Some insect species show a constancy for pollen collection from flowers of a given species at any particular time (Knapp, 1986; Linsley and Cazier, 1963; Rick et al., 1978). 
Symon (1976) suggested certain types of bees may have a closer dependence on Solanum pollen than initially thought.

Little or no seed set occurs in those species adapted to vibratile pollination if insects are not present (Bowers, 1975; Hardin et al., 1972). During the 1960s, while I was in Peru with Campbell Soup Co., we became interested in S. quitoense Lam., a species in the section Lasiocalpa. This species and related species are buzz pollinated (Whalen et al., 1981). Collections of $S$. quiroense were made from various areas in Peru and Ecuador. Collections were returned to Trujillo, Peru, and seeded there. Under no circumstances did we get fruit set in this area, although buzz pollinators should have been present because of proximity to wild tomatoes. Evidently, the Lycopersicon-pollinator relationship was not attuned to the Solanum introduction. Further, when S. quifoense was planted in California, no fruit set naturally, and fruit set was secured by hand pollination only. On transfer of this species ( $S$. quitoense) to Costa Rica and subsequently to Guatemala for commercial production, no fruit set problems resulted. A closely related species, $S$. candidum Lindl., occurs in this area (Whalen et al., 1981). An established pollinator-species relationship evidently existed there and was compatible with the introduced species. Heiser (1990) indicates that bumblebees pollinate $\mathrm{S}$. quitoense in Indiana and fruit set is not a problem there.

\section{VIBRATILE POLLINATION IN LYCOPERSICON}

Survival of vibratile-pollinated plant species in an alien environment may depend on floral adaptations because of poor seed set (Rick, 1950). The domestic tomato, L. esculentum, long considered to be self-pollinated (Rick, 1950), has been found to be facultative in its reproduction system, depending on conditions under which it is grown (Rick, 1949, 1950; Rick et al., 1978). The actual percentage of cross pollination in the species depended on the location (abundance and activity of insect vectors) and the genetic makeup of the variety-that is, its efficiency as a pollen or pistillate parent (Rick, 1949, 1950). In carefully designed experiments using male-sterile plants, Rick (1949, 1950) discovered cross-pollinations were caused by species of bees and that the percentage of cross-pollination varied from a low of $1 \%$ in certain California locations to $51 \%$ in Peru. Studies indicated a range of $41 \%$ to $51 \%$ in Peru compared with $1 \%$ to $33 \%$ in California (Rick, 1950). Insect-pollination trials with tomato in Mexico resulted in marked variation but relatively low set from location to location (Quiros and Marcias, 1978). Rick et al. (1978) pointed out that the species of Lycopersicon present a diversity of mating systems. Most of the wild species are largely insect pollinated. Notable exceptions are $L$. cheesmanii Riley in the Galapagos Islands and L. parviflorum Rick, Kes., Fob. \& Holle in the inter-Andean area of Peru. Rick (1950) attributed the tendency for L. esculentum to be self-pollinated to the fact that it was in an alien habitat, having been taken to North America and eventually to Europe where it was removed from the South American environment in which it would have been naturally insect pollinated. The self-pollination adoption was a selective condition for survival under these conditions. Lycopersicon cheesmanii is autogamous. Apparently, the only bee in the Galapagos that might buzz pollinate is the Galapagos carpenter bee, $X y$ locopa darwini Cockerell (Linsley et al., 1966). This bee, however, appears to have been introduced into the Galapagos relatively recently (Linsley et al., 1966), very likely after the establishment of $L$. cheesmanii. Consequently, it probably was not present during the evolutionary development of $L$. cheesmanii. Lycopersicon parviflorum is also autogamous, while L. chmielewskii Rick, Kes., Fob. \& Holle is facultative. Rick et al. (1976) discussed the evolution of $L$. parviflorum and suggested it may have evolved from $L$. chmielewskii. It became isolated from the former species because of the development of characteristics that failed to attract insects such as, as its name suggests, depauperate flowers. Lycopersicon parviflorum may have developed in an area outside the normal range of insects pollinating wild tomatoes.

\section{CONCLUSION}

Insect pollination appears to be an attractive alternative to hand pollination in hybrid tomato seed production where insect pollination would occur in conjunction with a male-sterile system. If sizeable quantities of seed could be produced by insect pollination, labor costs and consequently the cost of hybrid tomato seed would be markedly reduced. Even though the idea was proposed $>40$ years ago by Rick $(1949,1950)$, it has not become an accomplished fact. Rick (1949, 1950) indicated variation in insect pollinations from country to country, with maximum set in Peru, the native habitat of wild species. Pollinations from outcrossing occurred in California, but seed set was lower than in Peru with seed quantities highly variable from locale to locale. A similar situation occurs when $S$. quitoense is moved to various locations outside its natural habitat. Variation from place to place is best explained by the fact that pollinators vary in kind and number, and while pollinators may be present, strong pollinator-plant relationships may not be developed.

Much has been learned about vibratile pollination in Solanum and Lycopersicon in the past 40 years. However, information is still inadequate for production of hybrid tomato seed. Insufficient ecological informa- 
tion on pollinators is a major problem. Such information is needed to determine the best pollinators and best locations for development of these pollinators. Factors that attract pollinators to the crop have not been completely elucidated, although there is considerable information available. Little or nothing is known about how pollinators learn to vibrate the staminal cone or what stimulates them. Methods to enhance suitable insect populations are not known. For example, strategically used helper crops might enhance the desired population of insects by providing a constant source of energy (pollen). Which series of crops would provide the best results needs to be determined. Investigations to resolve these problems are needed if a system to employ insect pollination in Lycopersicon is to be achieved.

\section{Literature Cited}

Bowers, K.A.W. 1975. The pollination ecology of Solanum rostratum (Solanaceae). Amer. J. Bot. 62:633-638.

Buchmann, S.L. 1983. Buzz pollination in angiosperms, p. 73-113. In: C.E. Jones and R.J. Little (eds.). Handbook of experimental pollination biology. Van Norstrand Reinhold, New York.

Buchmann, S.L. 1986. Vibratile pollinations in Solanum and Lycopersicon: A look at pollen chemistry, p. 237-252. In: W.G. D’Arcy (ed.). Solanaceae. Biology and systematics. Columbia Univ., New York.
Buchmann, S.L., C.E. Jones, and L.J. Colin. 1977. Vibratile pollination of Solanum doughlasii and S. xanti (Solanaceae) in southern California. Wasmann J. Biol. 35:1-25.

Hardin, J.W., G. Doerksen, D. Herndon, M. Hobson, and F. Thomas. 1972. Pollination ecology and floral biology of four weedy genera in southern Oklahoma. Southwestern Naturalist 16:403-412.

Heiser, C. 1990. Lost crops of the Incas: Littleknown plants of the Andes with potential for worldwide cultivation. HortScience 25:589-590. (Book Rev.)

Knapp, S.D. 1986. Reproductive biology of Solanum section Geminata in a Costa Rican cloud forest, p. 253-263. In: W.G. D'Arcy (ed.). Solanaceae. Biology and systematics. Columbia Univ., New York.

Linsley, E.G. and M.A. Cazier. 1963. Further observations on bees which take pollen from plants of the genus Solanum. Pan-Pacific Entomol. 39:1-18.

Linsley, E.G., C.M. Rick, and S.G. Stephens. 1966. Observations on the floral relationships of the Galapagos carpenter bee. Pan-Pacific Entomol. 42:1-18.

Michener, C.D. 1962. An interesting method of pollen collecting by bees from flowers with tubular anthers. Rev. Biol. Trop. 10:167-175.

Quiros, C.F. and A. Marcias. 1978. Natural crosspollination and pollinator bees of the tomato in Celaya, Central Mexico. HortScience 13:290291.

Rick, C.M. 1947. The effect of planting design upon the amount of seed produced by malesterile tomato plants as a result of natural cross- pollination. Proc. Amer. Soc. Hort. Sci. 50:273284.

Rick, C.M. 1949. Rates of natural cross-pollination of tomatoes in various localities in California as measured by the fruits and seeds set on male-sterile plants. Proc. Amer. Soc. Hort. Sci. 54:237-252.

Rick, C.M. 1950. Pollination relations of Lycopersicon esculentum in native and foreign regions. Evolution 4:110-122.

Rick, C.M., M. Holle, and R.W. Thorp. 1978. Rates of cross-pollination in Lycopersicon pimpinellifolium: Impact of genetic variation in floral characters. Plant Systematics \& Evolution 129:31-44.

Rick, C.M., E. Kesicki, J.F. Fobes, and M. Holle. 1976. Genetic and biosystematic studies on two new sibling species of Lycopersicon from interandean Peru. Theoretical and Applied Genet. 47:55-68.

Symon, D.E. 1976 [1979]. Sex forms in Solanum (Solanaceae) and the role of pollen collecting insects, p. 385-397. In: J.G. Hawkes, R.N. Lester, and A.D. Skelding (eds.). The biology and taxonomy of the Solanaceae. Academic, London.

Whalen, M.D. 1984. Conspectus of species groups in Solarum subgenus Leptostemonum. Gentes Herbamm 12:179-282.

Whalen, M.D. and D.E. Costich. 1986. Andromonoecy in Solanum, p. 284-302. In: W.G. D'Arcy (ed.). Solanaceae. Biology and systematics. Columbia Univ., New York.

Whalen, M.D., D.E. Costich, and C.B. Heiser. 1981. Taxonomy of Solanum section Lasiocarpa. Gentes Herbarum 12:41-129. 